\begin{tabular}{c} 
PEDIOMATERNAL \\
NURSING JOURNAL \\
Vol. 5, No. 1, Maret 2019 \\
Jediomaternal \\
Journal Homepage: https://e-journal.unair.ac.id/PMNJ// \\
\hline
\end{tabular}

Original Research

\title{
Efektifitas Kompres Hangat dan Kompres Dingin terhadap Tingkat Nyeri Balita Pasca Outbreak Response Immunization (ORI)
}

\section{(The Effectiveness of Warm Compress and Cold Compress towards The Level of Pain in Toddler After Outbreak Response Immunization (ORI))}

\author{
Reza Dwi Agustiningrum, Mira Triharini, dan Praba Diyan Rachmawati \\ Fakultas Keperawatan, Universitas Airlangga, Surabaya, Jawa Timur, Indonesia
}

\author{
ARTICLE HISTORY \\ Received: March 17, 2019 \\ Accepted: April 8, 2019

\section{KEYWORDS} \\ cold compress; immunization; \\ pain; toddler; warm compress

\section{CORRESPONDING AUTHOR} \\ Reza Dwi Agustiningrum \\ reza.dwi.agustiningrum- \\ 2017@fkp.unair.ac.id \\ Fakultas Keperawatan, \\ Universitas Airlangga, Surabaya, \\ Jawa Timur, Indonesia
}

\begin{abstract}
Introduction: The Medical treatment which carried out by using needles, such as immunization, is a source of pain for children. the importance of evidence-based immunization strategies is used to reduce pain. Pain management with compresses that can be done before immunization in the injection area is considered capable of reducing pain in children. Warm compresses can cause physiological effects, the effects of giving warm compresses can reduce the pain. Cold compresses proved to be an effective way to reduce pain during immunization because it increases endorphins and suppresses prostaglandins so that it can increase pain thresholds. The purpose of this study is to explain the effectiveness of using warm compresses and cold compresses to the pain level in toddlers after ORI diphtheria immunization.
\end{abstract}

Methods: Analytical This study was pre-experimental with posttest only design. Data collection was carried out with FLACC scale sheets. The number of respondents as many as 66 toddlers was taken by inclusion and exclusion criteria with purposive sampling technique. Data were analyzed using Mann-Whitney analysis.

Results: the average pain in compress warm group of 4.48 in the cold compress 2.91 . However statistical test Mann-Whitney point a difference meaningful influence in both group on the pain of $p=0.001$. Cold compress more effective to reduce the pain with the mean the difference between of 25.41 than warm compress of 41.59

Conclusion: Increasing Cold compresses are more effective in reducing the level of pain in toddlers after ORI diphtheria immunization. Cold compresses with the temperature of $15^{\circ}$ c that were conducted before the act of injection can be used as the management of pain non pharmacology to lower the level of pain in toddler after ORI diphtheria immunization.

Agustiningrum, R. D., Triharini, M., \& Rachmawati, P. D. (2019). Efektifitas Kompres Hangat dan Kompres Dingin terhadap Tingkat Nyeri Balita Pasca Outbreak Response Immunization (ORI). Pediomaternal Nurs. J., 5(1), 57-62.

\section{PENDAHULUAN}

Setiap anak berhak memperoleh imunisasi dasar sesuai dengan ketentuan untuk mencegahterjadinya penyakit yang dapat dihindari melalui imunisasi (1). Tindakan medis yang dilakukan dengan menggunakan jarum, seperti imunisasi menjadi sumber rasa nyeri untuk anak-anak. Selain nyeri biasanya kecemasan, tekanan, dan rasa takut juga menjadi trauma yang akan berlanjut hingga dewasa (2). Oleh karena itu pentingnya strategi evidence- based imunisasi digunakan untuk mengurangi rasa nyeri. Hal ini sangat penting karena apabila tidak diberikan prosedur yang baik untuk mengurangi rasa nyeri pada awal masa anak dapat menyebabkan tanggapan rasa sakit yang akan berkontribusi pada gangguan perkembangan otak anak (3).

Cakupan imunisasi secara nasional sudah mencapai target tetapi masih banyak anak-anak yang sama sekali belum mendapatkan imunisasi atau belum lengkap imunisasinya. Menurut angka estimasi yang dikeluarkan oleh (4) hampir satu juta anak 
Indonesia tidak mendapatkan imunisasi sama sekali atau tidak lengkap status imunisasinya. Cakupan Bayi Laki-Laki dan Perempuan yang di imunisasi DPTHB3/DPT-HB-Hib3 sebanyak 553.848 bayi (97\%) dan belum memenuhi target. Target Imunisasi Dasar Lengkap (IDL) Provinsi Jawa Timur pada tahun 2016 adalah 91,5\%. Kabupaten/Kota yang IDLnya telah melampaui targetberjumlah 34 Kabupaten dan tinggal 4 kabupaten yang masih dibawah target yaitu Kabupaten Bangkalan, Pamekasan, Pacitan dan Ponorogo (1).

Capaian Universal Child Immunizatiom (UCI) di Puskesmas Pasean Kabupaten Pamekasan dalamtiga tahun terakhir yaitu di tahun 2015, 2016 dan 2017 adalah sebanyak $(11,11 \%),(44,44 \%)$ dan $(66,67 \%)$. Angkacakupan ini dianggap masih kurang dari target yang ditetapkan oleh Kemenkes yaitu sebesar 91,5\%. Rendahnya angka UCI di Puskesmas Pasean disebabkan oleh beberapa faktor yang dimungkinkan terjadi seperti ketakutan orang tua terhadap nyeri pasca imunisasi, tradisi dalam masyarakat untuk tidak imunisasi, dan kurangnya dukungan keluarga meskipun petugas kesehatan telah melakukan upaya peningkatan kualitas imunisasi yang dilaksanakan melalui kampanye, peningkatan skill petugas imunisasi, kualitas penyimpanan vaksin dan sweeping sasaran. Berdasarkan data yang didapat bahwa Kejadian Ikutan Pasca Imunisasi (KIPI) nyeri dan bengkak, di puskesmas pasean sebanyak 31 balita pasca kegiatan Outbreak Response Immunization (ORI) Difteri.

Berdasarkan studi pendahuluan yang dilakukan pada tanggal 18 Agustus 2018 di Puskesmas Pasean melalui wawancara terbuka pada 5 orang tua yang memiliki anak balita, setelah diberikan pertanyaan mengapa mereka tidak ingin melakukan imunisasi kepada balitanya. 5 dari 5 dengan prosentase $100 \%$ mengatakan bahwa mereka tidak ingin mengimunisasi balitanya dikarenakan dampak nyeri yang ditimbulkan pasca imunisasi sehingga membuat mereka panik dan trauma

Nyeri adalah perasaan yang tidak nyaman yang sangat subjektif dan hanya orang yang mengalaminya yang dapat menjelaskan dan mengevaluasi perasaan tersebut secara umum, nyeri dapat didefinisikan sebagai perasaan tidak nyaman, baik ringan maupun berat. Penanganan nyeri pada saat dilakukan imunisasi masih belum menjadi perhatian utama bagi tenaga kesehatan, hal tersebut disebabkan oleh beberapa hal, diantaranya adalah ketidakmampuan dalam menyampaikan rasa nyeri, keengganan menggunakan analgesik karena takut akan efek samping yang ditimbulkan serta kesalahan penafsiran ekspresi nyeri sebagai ekspresi rasa takut dan perhatian untuk mengutamakan penanganan pada penyakit dasarnya (6).

Manajemen nyeri adalah dengan metode farmakologi dan non farmakologi, metode non farmakologi salah satunya adalah dengan kompres yang dapat dilakukan sebelum imunisasi pada area injeksi dianggap mampu menurunkan nyeri pada anak. Pemberian kompres hangat sebelum tindakan penyuntikan dapat menurunkan skala nyeri pada bayi setelah dilakukan penyuntikan imunisasi (7). Kompres hangat dapat menimbulkan efek fisiologis, efek pemberian kompres hangat diantaranya dapat mengurangi nyeri (8). Sebuah penelitian lain menyatakan bahwa kompres es terbukti sebagai cara yang efektif untuk menurunkan nyeri saat imunisasi campak pada bayi karena meningkatkan endorphin dan menekan prostaglandin sehingga dapat meningkatkan ambang batas nyeri (9)

Terdapat beberapa tindakan yang dapat dilakukan setelah terjadi nyeri pasca imunisasi. Apabila tejadi nyeri dan bengkak yang timbul $<48$ jam setelah imunisasi maka dapat dilakukan kompres hangat dan diberikan obat antipiretik analgesik (10). Anjuran yang dapat dilakukan apabila ditempat suntikan timbul kemerahan, nyeri, dan pembengkakan maka dapat dianjurkan untuk memberikan kompres air dingin dan jika demam dapat diberikan antipiretik seperti paracetamol 15 $\mathrm{mg} / \mathrm{kg}$ bb setiap 3-4 jam (11).

Kenyamanan adalah pengalaman yang diterima oleh seseorang dari suatu intervensi. Hal ini merupakan pengalaman langsung dan menyeluruh ketika kebutuhan fisik, psikospiritual, sosial, dan lingkungan terpenuhi (12). Tindakan yang dapat dilakukan sebagai bentuk kenyamanan dan sebagai upaya pencegahan nyeri secara non farmakologi selama ini penelitiannya masih terbatas. Tujuan penelitian adalah menjelaskan efektifitas penggunaan kompres hangat dan kompres dingin terhadap penurunan nyeri pada balita pasca imunisasi ORI difteri.

\section{METODE}

\subsection{Desain}

Penelitian ini merupakan penelitian PraEksperimental dengan posttest only desain.

\subsection{Populasi, sampel, dan sampling}

Populasi dalam penelitian ini adalah balita yang diimunisasi ORI difteri di Puskesmas Pasean sejumlah 748 balita dan didapatkan 66 sampel dengan teori (13) jika peneliti melakukan penelitian eksprimental, peneliti dapat menentukan jumlah sampel minimum sebanyak 30 responden perkelompok dan ditambah 10\% kriteria dropout dari sampel yang dihitung yaitu sebanyak 3 orang per kelompok. Tekhnik sampling yang digunakan adalah purposive sampling. Penelitian dilakukan pada 22-30 November 2018. kriteria inklusinya adalah anak sehat dan tidak memiliki kontraindikasi terhadap imunisasi sebelumnya dan tidak mengkonsumsi agen farmakologi, kriteria eksklusi adalah anak yang menangis dan tidak dapat ditenangkan sembelum pemberian tindakan penyuntikan.

\subsection{Variabel}

Variabel independen dalam penelitian ini adalah kompres hangat dan kompres dingin. Variabel dependen dalam penelitian ini adalah tingkat nyeri. 


\subsection{Instrumen}

Penelitian ini menggunakan instrumen FLACC scale (14) dengan penilaian berdasar kategori Face, Leg, Activity, Cry, skala data ordinal dan dengan skoring 13 : nyeri ringan 4-6 : nyeri sedang 7-10 : nyeri berat tujuan penelitian dan orang tua responden untuk memberikan intervensi kompres hangat atau kompres dingin pada masing masing kelompok selama 15 menit sebelum diberikan suntikan imunisasi. Kompres hangat diberikan terlebih dahulu hingga selesai pada posyandu minggu ketiga

Tabel 1. Karakteristik Responden Penelitian Usia, Jenis Kelamin, Pekerjaan Orang Tua dan Yang Menamani Saat Imunisasi Pada Kompres Hangat Dan Kompres Dingin Di Puskesmas Pasean , November 2018

\begin{tabular}{|c|c|c|c|c|c|}
\hline \multirow{2}{*}{$\begin{array}{l}\text { Karakteristik Responden } \\
\text { Anak }\end{array}$} & \multicolumn{2}{|c|}{ Kompres Hangat } & \multicolumn{2}{|c|}{ Kompres Dingin } & \multirow{2}{*}{$\begin{array}{c}\text { Uji Homogenitas } \\
(>0,05)\end{array}$} \\
\hline & $\mathbf{n}$ & $\%$ & $\mathbf{n}$ & $\%$ & \\
\hline \multicolumn{6}{|l|}{ Usia : } \\
\hline $12-24$ bulan & 14 & 42,4 & 10 & 30,3 & \multirow{4}{*}{0,205} \\
\hline $25-36$ bulan & 14 & 42,4 & 12 & 36,4 & \\
\hline $37-48$ bulan & 5 & 15,2 & 11 & 33,3 & \\
\hline Total: & 33 & 100 & 33 & 100 & \\
\hline \multicolumn{6}{|l|}{ Jenis Kelamin : } \\
\hline Perempuan & 19 & 57,6 & 16 & 48,5 & \multirow{3}{*}{0,418} \\
\hline Laki-Laki & 14 & 42,4 & 17 & 51,5 & \\
\hline Total: & 33 & 100 & 33 & 100 & \\
\hline \multicolumn{6}{|l|}{ Karakterkistik Responden } \\
\hline \multicolumn{6}{|l|}{ Orang Tua } \\
\hline \multicolumn{6}{|l|}{$\begin{array}{l}\text { Yang menemani saat } \\
\text { imunisasi: }\end{array}$} \\
\hline Ibu & 25 & 75,8 & 22 & 66,7 & \multirow{4}{*}{0,451} \\
\hline Ibu dan Ayah & 7 & 21,2 & 8 & 24,2 & \\
\hline Nenek & 1 & 3,0 & 3 & 9,1 & \\
\hline Total: & 33 & 100 & 33 & 100 & \\
\hline
\end{tabular}

Tabel 2. Tingkat NyeriKelompok Kompres Hangat Dan Kompres Dingin Pada Balita Pasca Imunisasi ORI Difteri di Puskesmas Pasean, November 2018

\begin{tabular}{|c|c|c|c|c|c|c|}
\hline & $\mathbf{n}$ & $\%$ & Mean & SD & Minimal & Maksimal \\
\hline \multicolumn{7}{|c|}{ Kompres Hangat } \\
\hline Nyeri Ringan & 11 & 33.3 & \multirow{4}{*}{4.48} & \multirow{4}{*}{1.922} & \multirow{4}{*}{2} & \multirow{4}{*}{10} \\
\hline Nyeri Sedang & 18 & 54.5 & & & & \\
\hline Nyeri Berat & 4 & 12.1 & & & & \\
\hline Total: & 33 & 100.0 & & & & \\
\hline \multicolumn{7}{|c|}{ Kompres Dingin } \\
\hline Nyeri Ringan & 23 & 69.7 & \multirow{5}{*}{2.91} & \multirow{5}{*}{1.466} & \multirow{5}{*}{1} & \multirow{5}{*}{6} \\
\hline Nyeri Sedang & 10 & 30.3 & & & & \\
\hline Nyeri Berat & - & - & & & & \\
\hline Total: & 33 & 100.0 & & & & \\
\hline $\mathrm{p}$ value & 0.001 & & & & & \\
\hline
\end{tabular}

\subsection{Prosedur}

Jumlah responden terjangkau sebanyak 276 yang diambil sejumlah 66 responden dan dibagi menjadi dua kelompok perlakuan berdasarkan usiatoddler (13 tahun) yaitu sebanyak 33 responden untuk perlakuan kompres hangat dan 33 responden untuk perlakuan kompres dingin.

Pada saat hari pengambilan data peneliti memberikan lembar persetujuan kepada orangtua responden untuk menjadi responden dan dijelaskan tujuan dari penelitian, apabila setuju maka peneliti mengajarkan orang tua cara menilai intensitas nyeri kepada balitanya dengan menggunakan skala FLACC dan apabila orangtua responden sudah memahami kemudian peneliti melakukan intervensi yang dibantu oleh bidan yang bertugas untuk menjelaskan sedangkan kompres dingin diberikan pada saat posyandu minggu keempat.

Kompres hangat atau kompres dingin dilakukan sebelum tindakan penyuntikan. Peneliti mempertahankan suhu kompres selama 15 menit dengan cara mengukur suhu secara berkala dengan menggunakan termometer air. Balita diposisikan dengan dipangku dan didekap oleh ibu atau keluarga yang mengantar saat imunisasi.Selanjutnya peneliti melakukan posttest yaitu bersama dengan orang tua mengamati dan melakukan observasi nyeri pada balita dengan menggunakan skala nyeri FLACC dan segera menganalisis tingkat skala nyeri pada balita tersebut segera setelah imunisasi, apabila jumlah balita yang hadir di posyandu tidak memenuhi syarat maka peneliti melakukan sweeping antar rumah untuk melakukan tindakan yang sama. 


\subsection{Analisis}

Penelitian ini dilakukan analisis dengan IBM SPSS Statistic 25 dengan uji Mann-Whitney $\alpha \leq 0.05$.

\subsection{Ethical Clearance}

Penelitian ini telah dinyatakan lolos kaji etik dan mendapatkan sertifikat Ethical Approval dengan No. 1207-KEPK yang dikeluarkan oleh Komite Etik Penelitian Kesehatan Fakultas Keperawatan Universitas Airlangga pada tanggal 7 Desember 2018.

\section{Hasil}

Distribusi usia responden didapatkan jumlah yang sama pada kelompok perlakuan kompres hangat yaitu hampir setengahnya sebanyak 14 responden $(42,4 \%)$ pada usia 12-24 bulan dan usia 25-36 bulan sedangkan pada kelompok perlakuan kompres dingin menunjukkan bahwa hampir setengahnya usia responden adalah 25-36 bulan sebanyak 12 responden $(36,4 \%)$. Jenis kelamin responden pada kelompok perlakuan kompres hangat sebagian besar statistic Mann-Whitney test pada kelompok kompres hangat dan kompres dingin, maka didapatkan hasil nilai $p$ value adalah 0,001 (p value $<0,05$ ) [Tabel 3].

\section{PEMBAHASAN}

4.1 Pengaruh kompres hangat terhadap tingkat nyeri pada balita pasca imunisasi ORI difteri

Pemberian kompres hangat dapat berpengaruh terhadap respon nyeri pada balita saat imunisasi. Nyeri dapat didefinisikan sebagai perasaan tidak nyaman, baik ringan maupun berat. Penanganan nyeri pada saat dilakukan imunisasi masih belum menjadi perhatian utama bagi tenaga kesehatan, hal tersebut disebabkan oleh beberapa hal, diantaranya adalah ketidakmampuan dalam menyampaikan rasa nyeri, keengganan menggunakan analgesik karena takut akan efek samping yang ditimbulkan serta kesalahan penafsiran ekspresi nyeri sebagai ekspresi rasa takut dan perhatian untuk mengutamakan penanganan pada penyakit dasarnya (6). Faktorfaktor yang mempengaruhi nyeri adalah usia, jenis

Tabel 3. EfektifitasKompres Hangat Dan Dingin Terhadap Tingkat Nyeri Pada Balita Pasca Imunisasi ORI Difteri di Puskesmas Pasean, November 2018

\begin{tabular}{lcc}
\hline Variabel & Mean Selisih & p Value \\
\hline Kompres Hangat & 41,59 & 0,001 \\
Kompres Dingin & 25,41 & \\
${ }^{\times}$Mann-Whitney test & $\mathrm{p} \leq 0,05$ \\
×Signifikan & \\
\hline
\end{tabular}

adalah berjenis kelamin perempuan sejumlah 19 responden $(57,6 \%)$ sedangkan pada kelompok perlakuan kompres dingin didapatkan sebagian besar responden adalah berjenis kelamin laki-laki sebanyak 17 responden (51,5\%).Orang yang menemani saat imunisasi pada kelompok kompres hangat sebagian besar adalah ibu sebanyak 25 responden $(75,8 \%)$ sedangkan pada kompres dingin sebagian besar adalah ibu sebanyak 22 responden (66,7\%). Berdasarkan hasil uji homogenitas pada data karakteristik responden didapatkan semua data homogen $(>0,05)$ dengan nilai usia 0.205 , nilai jenis kelamin 0.418 dan nilai data yang mendampingi saat imunisasi sebesar 0,45 [Tabel 1].

Tingkat nyeri pada kompres hangat dan kompres dingin pada Balita usia 1-3 tahun menunjukkan bahwa pada kelompok perlakuan kompres hangat didapatkan data sebagian besar balita dengan tingkat nyeri sedang sejumlah 18 responden (54,5\%) dan pada kelompok kompres dingin sebagian besar mengalami tingkat nyeri ringan yaitu sebanyak 23 responden $(69,7 \%)$. Nilai mean pada kelompok kompres hangat sebesar 4,48 dan pada kompres dingin sebesar 2,91 [Tabel 2].

Hasil dari efektifitas kompres hangat dan kompres dingin pada Balita usia 1-3 tahun adalah kompres dingin lebih efektif dibandingkan dengan kompres hangat dikarenakan nilai mean pada kelompok kompres hangat sebesar 41,59 sedangkan pada kelompok kompres dingin 25,4. Berdasarkan hasil uji kelamin, kebudayaan, makna nyeri, perhatian klien, ansietas, keletihan, pengalaman sebelumnya, gaya koping, dukungan keluarga dan sosial.

Pada kelompok kompres hangat mayoritas responden adalah perempuan, dan berdasarkan tingkat nyeri didapatkan bahwa perempuan lebih berespon terhadap nyeri dibandingkan dengan jenis kelamin laki-laki. Hal tersebut sesuai dengan teori dari (15) yang mengatakan bahwa jenis kelamin secara umum pria dan wanita tidak berbeda secara bermakna dalam berespon terhadap nyeri, toleransi terhadap nyeri dipengaruhi oleh kebudayaan. Beberapa kebudayaan mempengaruhi jenis kelamin dalam menilai nyeri (misalnya anak laki-laki tidak boleh menangis, sedangkan perempuan boleh menangis dalam keadaan yang sama).

Pemberian kompres hangat mampu untuk mengatasi nyeri, hal tersebut juga sesuai dengan penelitian lain yang mengatakan bahwa kompres hangat dapat mengurangi nyeri dengan cara melebarkan pembuluh darah dan meningkatkan aliran darah lokal sehingga menurunkan kontraksi otot polos myometrium dan kontriksi pembuluh darah (16). Mekanisme kompres hangat dapat mengurangi respon nyeri karena pemberian kompres hangat yang menimbulkan efek hangat dapat menyebabkan terlepasnya endorphin sehingga memblok transmisi nyeri. Endorphin merupakan asam amino yang mengikat reseptor opiat yang berada di otak yang dapat memberi efek analgesik. 
Penggunaan kompres hangat terhadap respon nyeri bayi saat imunisasi DPT-HB menunjukkan bahwa terdapat pengaruh kompres hangat terhadap respon bayi (7).

Kompres hangat adalah tindakan yang dapat dilakukan untuk menurunkan tingkat nyeri dan merupakan salah satu manajemen nyeri yang dapat diberikan kepada balita karena tidak menyebabkan komplikasi atau kontraindikasi seperti manajemen penanganan nyeri menggunakan farmakologi. Berdasarkan penelitian yang dilakukan oleh peneliti maka peneliti berpendapat bahwa dengan pemberian kompres hangat pada tempat penyuntikkan sebelum dilakukan imunisasi dapat mengurangi respon nyeri yang dirasakan oleh balita sehingga hal tersebut mampu membuat balita merasa nyaman dan tidak menyebabkan trauma yang akan dibawa hingga masa dewasa.

\subsection{Pengaruh kompres dingin terhadap tingkat} nyeri pada balita pasca imunisasi ORI difteri

Kompres dingin berpengaruh terhadap penurunan tingkat nyeri pada balita usia 1-3 tahun pasca imunisasi ORI difteri hal tersebut sesuai dengan teori dari penelitian lain yang mengatakan bahwa kompres dingin dapat meminimalisir nyeri imunisasi pada anak usia toddler (17). Kompres dingin dapat membuat kulit menurunkan respon nyeri karena adanya pelepasan endorphin sehingga dapat memblokir transmisi serabut saraf sensori A-beta yang lebih besar dan lebih cepat, juga dapat menurunkan transmisi nyeri pada serabut $\mathrm{C}$ dan delta A sehingga gerbang sinaps menutup transmisi implus nyeri (18).

Kompres dingin mampu menjadi anastesi local yang memiliki keuntungan terapeutik untuk mengurangi nyeri lokal seperti nyeri penyuntikan (15). Tindakan penyuntikan pada saat imunisasi dapat menyebabkan trauma pada balita dan akan terus berlanjut sebagai pengalaman yang tidak menyenangkan. Kompres es bila diberikan pada sumber nyeri seperti tusukan jarum dapat menurunkan produksi prostaglandin sehingga sensitivitas reseptor nyeri berkurang (19). Dalam penelitian lain menyatakan bahwa kompres es terbukti sebagai cara yang efektif, mudah dan hemat yang dapat dilakukan untuk menurunkan tingkat nyeri terutama nyeri saat imunisasi campak pada bayi usia 9 bulan (9).

Dalam penelitian ini pada kelompok kompres dingin mayoritas responden berusia 1-2 tahun dan yang paling rentan terhadap respon nyeri adalah pada usia 12-24 bulan. hal tersebut sesuai dengan teori (15) bahwa usia anak yang masih kecil mempunyai kesulitan memahami nyeri dan prosedur yang dilakukan perawat yang menyebabkan nyeri sehingga perawat harus mengkaji respon nyeri. Balita mengalami kesulitan untuk mengartikan rasa nyeri dan menyampaikan rasa nyeri yang dialami, biasanya balita hanya akan menyampaikan rasa nyeri dengan tangisan atau ekspresi wajah dan dengan kata sederhana bagi balita yang sudah mampu berbicara.
Menurut peneliti seorang perawat sebaiknya mampu membantu klien untuk mengurangi atau menghilangkan rasa nyeri yang ditimbulkan dari tindakan penyuntikan imunisasi. Rasa nyeri yang ditimbulkan pada saat imunisasi menyebabkan orang tua tidak memberikan imunisasi pada anaknya hal tersebut akan berdampak terhadap kejadian luar biasa, tujuan dari imunisasi adalah untuk mencegah penyakit yang dapat dicegah dengan imunisasi. Salah satu cara yang dapat dilakukan untuk menurunkan tingkat nyeri pada balita yang diberikan imunisasi ORI difteri adalah dengan penanganan nyeri non farmakologis yaitu melalui tindakan kompres dingin.

4.3 Perbedaan efektifitas penggunaan kompres hangat dan kompres dingin terhadap tingkat nyeri pada balita pasca imunisasi ORI difteri

Penggunaan kompres hangat dan kompres dingin terbukti dapat mempengaruhi tingkat nyeri pada balita yang mendapatkan suntikan imunisasi ORI, akan tetapi dalam penelitian ini kompres dingin lebih efektif dibandingkan dengan kompres hangat. Teori gate kontrol dari (20) mengusulkan bahwa kompres dingin mampu menahan implus dari nyeri dapat diatur atau dihambat oleh mekanisme pertahan yang ada di sepanjang system saraf pusat. Teori tersebut menyatakan bahwa implus nyeri dihantarkan saat sebuah pertahanan dibuka dan implus dihambat saat sebuah pertahanan tertutup. Upaya menutup pertahanan tersebut merupakan dasar teori menghilangkan nyeri. pelepasan endorphin dapat memblokir transmisi serabut saraf sensori A-beta yang lebih besar dan lebih cepat, juga dapat menurunkan transmisi nyeri pada serabut $\mathrm{C}$ dan delta A sehingga gerbang sinaps menutup transmisi implus nyeri (21). Kompres hangat dapat menurunkan nyeri dengan memberikan energi panas melalui proses konduksi, dimana panas yang dihasilkan dapat menyebabkan vasodilatasi yang menyebabkan pelebaran pembuluh darah local. Kompres hangat dapat memberikan rasa hangat untuk mengurangi nyeri karena adanya pelebaran pembuluh darah sehingga meningkatkan aliran darah local dan memberukan rasa nyaman (22).

Dukungan keluarga juga berperan terhadap penurunan tingkat nyeri yaitu pada penelitian ini didapatkan data bahwa semua reponden yang menemani saat imunisasi adalah keluarganya dan sebagian besar ditemani oleh ibu sehingga hal tersebut terkait dengan kedekatan ibu terhadap anak lebih daripada kedekatan ayah ataupun nenek kepada anak. Kedekatan ibu akan memberikan ketenangan pada anak sehingga dapat mempengaruhi tingkat nyeri, hal tersebut sesuai dengan teori (12) yang mengatakan bahwa kenyamanan pada anak juga akan terpenuhi khususnya kenyamanan psikologis dan sosiokultural. Kompres hangat dan kompres dingin tidak menunjukkan perbedaan yang signifikan terhadap tingkat nyeri, namun jika dibandingkan kompres hangat lebih menunjukkan hasil yang lebih besar perbedaannya jika dibandingkan dengan kompres 
dingin dengan nilai mean 41,59. Oleh karena itu kompres dingin lebih efektif terhadap tingkat nyeri saat imunisasi ORI difteri.

\section{KESIMPULAN}

Penggunaan kompres hangat dengan suhu $40^{\circ} \mathrm{C}$ selama 15 menit sebelum penyuntikan dapat menurunkan tingkat nyeri pada balita pasca imunisasi ORI difteri, Penggunaan kompres dingin dengan suhu $16^{\circ} \mathrm{C}$ selama 15 menit sebelum penyuntikan dapat menurunkan tingkat nyeri pada balita pasca imunisasi ORI difteri, Kompres dingin lebih efektif dalam menurunkan tingkat nyeri pada balita pasca imunisasi ORI difteri dan dapat dilakukan secara mandiri oleh pelayanan kesehatan dan orang tua balita.

\section{UCAPAN TERIMA KASIH}

Kami mengucapkan terima kasih kepada Kepala Puskesmas Pasean untuk izin dan penerimaan kami untuk mengambil data sebagai bahan penelitian dan semua responden yang telah bersedia dalam penelitian ini.

\section{DAFTAR PUSTAKA}

1. Kemenkes RI. Profil Kesehatan Indonesia. 2016.

2. Canbulat Şahiner N, Inal S, Sevim Akbay A. The Effect of Combined Stimulation of External Cold and Vibration During Immunization on Pain and Anxiety Levels in Children. J Perianesthesia Nurs. 2015;30(3):228-35.

3. Harrison D, Sampson M, Reszel J, Abdulla K, Barrowman N, Cumber J, et al. Too many crying babies: A systematic review of pain management practices during immunizations on YouTube. BMC Pediatr. 2014;14(1):1-8.

4. Yousefichaijan $P$, Salehi B, Rafiei M, Dahmardnezhad M, Naziri M. The correlation between attention deficit hyperactivity disorder and steroid-dependent nephrotic syndrome. Saudi J Kidney Dis Transplant [Internet]. 2015 Nov 1 [cited 2018 Mar 7];26(6):1205. Available from:

http://www.sjkdt.org/text.asp?2015/26/6/12 $05 / 168624$

5. WHO. World Health Statistic. Vol. 151. 2015. 10$17 \mathrm{p}$.

6. Clara LA. Pengaruh Pemberian Glukosa Oral 40\% Terhdap Respon Nyeri Pada Bayi Yang Dilakukan Imunisasi Pentavalen Di Puskesmas Baki Sukoharjo. 2015;

7. Arianto Yusni. Pengaruh Kompres Hangat Terhadap Respon Nyeri Bayi Saat Imunisasi DPT-HB Di Wilayah Kerja Puskesmas Semarang. 2016;
8. Wahit MI, Lilis I, Joko S. Buku Ajar Ilmu Keperawatan Dasar. Jakarta Selatan; 2015.

9. Lingga AL. Pengaruh Kompres Es Terhadap Tigkat Nyeri Saat Imunisasi Campak PAda Bayi Usia 9 Bulan Di Desa Sanggung Sukoharjo. 2015;

10. Permenkes RI no 12. Peraturan Menteri Kesehatan Republik Indonesia Nomor 12 Tahun 2017 tentang Penyelenggaraan Imunisasi. 2017;1-162.

11. IDAI. Penjelasan Kepada Orang Tua Mengenai Imunisasi. 2013.

12. Kolcaba K, Ohio C, Dimarco MA. Comfort Theory and its application to pediatric nursing. 2015;(May 2005).

13. Fraenkel RJ, Wallen EN. How to Design and Evaluate Research in Education. McGraw-Hill Education; 2011.

14. MassGeneral Hospital for Children. R-FLACC Scale Face, Legs, Activity, Cry, Consolability. 2009;10-1.

15. Perry, Potter. Clinical Nursing Skill \& Techniques. 8th ed. Riverport Lane: Elsevier Inc.; 2014.

16. Bonde FMP, Moningka M. Pengaruh Kompres Panas Terhadap Penurunan Derajat Nyeri Haid Pada Siswi Sma Dan Smk Yadika Kopandakan Ii. J e-Biomedik. 2014;2(1):2-6.

17. Jayaraman U, Jose J. Effect of ice application in reducing pain perception of toddlers during immunization. Int J Recent Sci. 2018;4(May):37.

18. Endah S. Pengaruh Pemberian Kompres Es Batu Terhadap Penurunan Tingkat Nyeri Pada Anak Usia Pra Sekolah yang Dilakukan Prosedur Pemasangan Infus di RSUPN Dr. Cipto Mangunkusumo Jakarta. PRIMA J Ilm Ilmu Kesehat. 2015;1.

19. Muttaqin A. Buku Ajar Asuhan Keperawatan Klien Dengan Gangguan Sistem Persyarafan. Jakarta: Salemba Medika; 2008.

20. Melzack R, Wall P. Handbook Of Pain Management. 1st ed. Churchill Livingstone; 2003. 744 p.

21. Sulistiyani. Pengaruh Pemberian Kompres Es Batu Terhadap Tingkat Nyeri Pada Anak Usia Pra Sekolah Yang Dilakukan Prosedur Pemasangan Infus Di Rumah Sakit Umum Pusat dr. Cipto Mangunkusumo Jakarta. Ilmu Keperawatan Anak UI. 2009;

22. Price AS, Lorraine MW. Patofisiologi : Konsep Klinis Proses-Proses Penyakit. 4th ed. Jakarta: EGC; 2005. 